\title{
Evaluation of Heavy Metals in Sediments of River Ethiope, Delta State, Nigeria
}

\author{
*Osakwe, S.A. and Peretiemo-Clarke, B.O. \\ Department of Chemistry, Delta State University, Abraka.
}

\begin{abstract}
This study presents concentration levels of $\mathrm{Fe}, \mathrm{Mn}, \mathrm{Cu}, \mathrm{Cr} . \mathrm{Cd} \mathrm{Ni}, \mathrm{V}$ and $\mathrm{Pb}$ in sediments of River Ethiope. The levels fell within the following ranges $\left(\mathrm{mgkg}^{-1}\right), 0.21-0.46$ for Mn, 0.84-2.24 for Zn, 0.34-0.60 for $\mathrm{Cu}, 0.00$ - 0.11 for $\mathrm{Cd}$, 0.005-0.49 for $\mathrm{Ni}, 0.00-0.05$ for $\mathrm{V}$ and 0.27-0.72 for $\mathrm{Pb}$. $\mathrm{Cr}$ was not detected in any of the samples. The observed concentrations of the metals are mainly due to anthropogenic effects. There seems to be no imminent danger to the living organisms in the environment since the low levels observed do not pose any environmental contamination risk. Three correlation levels were observed. In group $\mathrm{I}, \mathrm{Cr}, \mathrm{Zn}, \mathrm{Ni}$ and $\mathrm{V}$ strongly correlated with each other. In group 2, $\mathrm{Fe}, \mathrm{Zn} ; \mathrm{Mn}$. $\mathrm{Cu}$ and $\mathrm{Ni}$ displayed positive correlation at different levels with each other while in group $3, \mathrm{~Pb}$ and $\mathrm{Cd}$ did not correlate with any of the metals. The levels reported have an abundance ratio in order $\mathrm{Zn}>\mathrm{Pb}>\mathrm{Cu}>\mathrm{Mn}>\mathrm{Ni}>\mathrm{Cr}$.

Key Words: Environmental pollution, heavy metals, River Ethiope, sediments.
\end{abstract}

\section{Introduction}

Sediments are components of our environment that serve as repositories for deleterious chemical species ${ }^{[1]}$ because of anthropogenic wastes discharged into water bodies ${ }^{[2]}$. They conserve important environmental information and are increasingly recognized as both carriers and possible source of contaminants in aquatic system ${ }^{[3]}$.

Studies have shown that many water bodies in Nigeria contain various levels of heavy metal pollutants $^{[4,5,6,7]}$. Metals dissolved in soil solution, surface and interstitial waters and those adsorbed to the sediment by cation exchange process are usually readily available to aquatic and benthic organisms as well as plants $^{[8]}$.

The behaviour and biological impact of heavy metals pollutants in aquatic systems is governed by factors such as adsorption, desorption, sedimentation-resuspension, filtration, complexation, precipitationsolubilization, biological uptake and excretion ${ }^{[9,10]}$.

River Ethiope is used extensively for recreational and occupational activities such a fishing, swimming, washing, bathing and other domestic purposes. Since the river passes through many towns and villages, some unfriendly activities such as dumping of waste from consumer products by local residents along the banks of the river may lead to contamination and pollution of the water body. In addition, during the rainy season, Ethiope River overflows its bank annually and as such carry all the domestic wastes into the river along with runoffs from rains.

The objectives of this study were to establish the presence and levels of heavy metals in the river sediments and to identify the sources of these metal pollutants. The results of this study will provide useful information, about the pollution status of the river.

\section{Study Area}

\section{Materials and Methods}

River Ethiope (latitude $6^{\circ} 00-6^{\circ} 30 \mathrm{~N}$ and longitude $5^{\circ} 00-6^{\circ} \mathrm{OOE}$ ) is a clear oligoinic fresh water river which took its source from Umuaja in Ukwuani Local Government Area of Delta State flows westward for about $10 \mathrm{~km}$ before it discharges into Benin River at Sapele. The substratum consists mainly of sand and is vegetated in the non-tidal zone and mainly muddy sediments in the tidal area ${ }^{[11]}$. The river stretches from Umuaja through Obiaruku, Abraka, Eku, Aghalokpe, Mosoga down to Sapele.

\section{Sampling}

Sediment samples were collected at five sites along the stretch of the river in March and July representing dry and rainy seasons respectively. Sampling points were centred mainly on the towns along the river course. The samples were air-dried at room temperature and subsequently kept for 1 hour in an oven at $100^{\circ} \mathrm{C}$. The dried sediments were ground in a porcelain mortar with a pestle and sieved to particle size of $200 \mathrm{~mm}$. 


\section{Sample Preparation}

$1.0 \mathrm{~g}$ of each of the samples was digested with a mixture of hydrofluoric, nitric, perchloric and sulphuric $\left(\mathrm{HF}-\mathrm{HNO}_{3}-\mathrm{HCIO}_{4}-\mathrm{H}_{2} \mathrm{SO}_{4}\right)$ acids. The clear digest was diluted to $50 \mathrm{~cm}^{3}$ with distilled deionized water. The sample solutions were analyzed for the metals using air-acetylene flame atomic absorption spectrophotometer (AAS) (Perkin Elmer A3 100) fitted with $\mathrm{D}_{2}$ background correction device.

\section{Results and Discussion}

The results of heavy metals concentrations (in $\mathrm{mgkg}^{-1}$ dry weight) from the sediment samples in the five sampling sites for dry and wet seasons together with their mean values are presented on table 1 .

Table 1: Concentration levels (mgkgt) of $\mathrm{Zn}, \mathrm{Pb}, \mathrm{Fe}, \mathrm{Ni} . \mathrm{Mn}, \mathrm{Cu}, \mathrm{Cr} . \mathrm{Cd}$ and $\mathrm{V}$ in sediments of River Ethiope. Key

\begin{tabular}{|c|c|c|c|c|c|c|c|c|c|c|c|c|c|c|c|c|}
\hline $\begin{array}{l}\mathrm{Pa} \\
\mathrm{ra} \\
\mathrm{m} \\
\text { et } \\
\mathrm{e}\end{array}$ & $\mathrm{U}_{1}$ & $\mathrm{U}_{2}$ & $\begin{array}{c}\mathrm{Me} \\
\text { an }\end{array}$ & $\mathrm{O}_{1}$ & $\mathrm{O}_{2}$ & $\begin{array}{l}\text { Me } \\
\text { an } \\
X\end{array}$ & $\begin{array}{c}\mathrm{Ab} \\
\mathrm{k}_{1}\end{array}$ & $\begin{array}{c}\text { Abk } \\
2\end{array}$ & $\begin{array}{c}\mathrm{Me} \\
\text { ans } \\
\mathrm{X}\end{array}$ & $\mathrm{A}_{1}$ & $\mathrm{~A}_{2}$ & $\begin{array}{c}\text { Me } \\
\text { an } \\
X\end{array}$ & $\mathrm{~S}_{1}$ & $\mathrm{~S}_{2}$ & $\begin{array}{c}\mathrm{Me} \\
\text { an } \\
\mathrm{X}\end{array}$ & $\begin{array}{c}\text { Wor } \\
\text { ld } \\
\text { Aver } \\
\text {. } \\
\text { Leve } \\
1 \text { in } \\
\text { ppm }\end{array}$ \\
\hline $\mathrm{Zn}$ & $\begin{array}{l}1.0 \\
2\end{array}$ & $\begin{array}{l}0.8 \\
0\end{array}$ & $\begin{array}{l}0.9 \\
1\end{array}$ & 2.04 & $\begin{array}{l}2.0 \\
8\end{array}$ & $\begin{array}{l}2.0 \\
6\end{array}$ & $\begin{array}{l}1 . \\
52\end{array}$ & 1.41 & $\begin{array}{l}1.4 \\
7\end{array}$ & $\begin{array}{l}0 . \\
97\end{array}$ & $\begin{array}{l}1.0 \\
0\end{array}$ & $\begin{array}{l}0.8 \\
4\end{array}$ & 2.25 & $\begin{array}{l}2.2 \\
3\end{array}$ & $\begin{array}{l}2.2 \\
4\end{array}$ & 1 \\
\hline $\mathrm{Pb}$ & $\begin{array}{l}0.4 \\
5\end{array}$ & $\begin{array}{l}0.3 \\
9 \\
\end{array}$ & $\begin{array}{l}0.4 \\
2\end{array}$ & 0.66 & $\begin{array}{l}0.6 \\
2\end{array}$ & $\begin{array}{l}0.6 \\
4\end{array}$ & $\begin{array}{l}0 . \\
68\end{array}$ & 0.63 & $\begin{array}{l}0.6 \\
6 \\
\end{array}$ & $\begin{array}{l}0 . \\
24\end{array}$ & $\begin{array}{l}0.2 \\
9 \\
\end{array}$ & $\begin{array}{l}0.2 \\
7 \\
\end{array}$ & 0.74 & $\begin{array}{l}0.6 \\
9 \\
\end{array}$ & $\begin{array}{l}0.7 \\
2\end{array}$ & 100 \\
\hline $\mathrm{Fe}$ & $\begin{array}{l}2.3 \\
0\end{array}$ & $\begin{array}{l}2.3 \\
0\end{array}$ & $\begin{array}{l}0.3 \\
0\end{array}$ & 4.50 & $\begin{array}{l}0.4 \\
0\end{array}$ & $\begin{array}{l}0.4 \\
0\end{array}$ & $\begin{array}{l}4 . \\
90\end{array}$ & 4.95 & $\begin{array}{l}4.9 \\
3\end{array}$ & $\begin{array}{l}3 . \\
75\end{array}$ & $\begin{array}{l}3.7 \\
4\end{array}$ & $\begin{array}{l}3.7 \\
45\end{array}$ & 3.40 & $\begin{array}{l}3.6 \\
0\end{array}$ & $\begin{array}{l}3.5 \\
0\end{array}$ & $\begin{array}{l}3800 \\
0\end{array}$ \\
\hline $\mathrm{Ni}$ & $\begin{array}{l}0.0 \\
0\end{array}$ & $\begin{array}{l}0.0 \\
1\end{array}$ & $\begin{array}{l}0.0 \\
05\end{array}$ & 0.52 & $\begin{array}{l}0.4 \\
5\end{array}$ & $\begin{array}{l}0.4 \\
5\end{array}$ & $\begin{array}{l}0 . \\
39\end{array}$ & 0.64 & $\begin{array}{l}0.5 \\
2\end{array}$ & $\begin{array}{l}0 . \\
75\end{array}$ & $\begin{array}{l}0.4 \\
0\end{array}$ & $\begin{array}{l}0.5 \\
5\end{array}$ & 0.84 & $\begin{array}{l}0.6 \\
3\end{array}$ & $\begin{array}{l}0.7 \\
4\end{array}$ & 40 \\
\hline $\begin{array}{l}\mathrm{M} \\
\mathrm{n}\end{array}$ & $\begin{array}{l}0.4 \\
1 \\
\end{array}$ & $\begin{array}{l}0.3 \\
5 \\
\end{array}$ & $\begin{array}{l}0.3 \\
8 \\
\end{array}$ & 0.52 & $\begin{array}{l}0.4 \\
0 \\
\end{array}$ & $\begin{array}{l}0.4 \\
0 \\
\end{array}$ & $\begin{array}{l}0 . \\
34 \\
\end{array}$ & 0.25 & $\begin{array}{l}0.3 \\
0\end{array}$ & $\begin{array}{l}0 . \\
70\end{array}$ & $\begin{array}{l}0.3 \\
0\end{array}$ & $\begin{array}{l}0.4 \\
0\end{array}$ & 0.25 & $\begin{array}{l}0.1 \\
6\end{array}$ & $\begin{array}{l}0.2 \\
1\end{array}$ & 850 \\
\hline $\begin{array}{l}\mathrm{C} \\
\mathrm{u}\end{array}$ & $\begin{array}{l}0.4 \\
4 \\
\end{array}$ & $\begin{array}{l}0.3 \\
4 \\
\end{array}$ & 034 & 0.44 & $\begin{array}{l}0.4 \\
4 \\
\end{array}$ & $\begin{array}{l}0.4 \\
4 \\
\end{array}$ & $\begin{array}{l}0 . \\
45 \\
\end{array}$ & 0.43 & $\begin{array}{l}0.4 \\
4 \\
\end{array}$ & $\begin{array}{l}0 . \\
50 \\
\end{array}$ & $\begin{array}{l}0.3 \\
7 \\
\end{array}$ & $\begin{array}{l}0.3 \\
8 \\
\end{array}$ & 0.61 & $\begin{array}{l}0.5 \\
9 \\
\end{array}$ & $\begin{array}{l}0.6 \\
0 \\
\end{array}$ & 20 \\
\hline $\mathrm{Cr}$ & $\begin{array}{l}0.0 \\
0 \\
\end{array}$ & $\begin{array}{l}0.0 \\
0 \\
\end{array}$ & $\begin{array}{l}0.0 \\
0 \\
\end{array}$ & 0.00 & $\begin{array}{l}0.0 \\
0 \\
\end{array}$ & $\begin{array}{l}0.0 \\
0 \\
\end{array}$ & $\begin{array}{l}0 . \\
00 \\
\end{array}$ & 0.00 & $\begin{array}{l}0.0 \\
0 \\
\end{array}$ & $\begin{array}{l}0 . \\
00 \\
\end{array}$ & $\begin{array}{l}0.0 \\
0 \\
\end{array}$ & $\begin{array}{l}0.0 \\
0 \\
\end{array}$ & 0.00 & $\begin{array}{l}0.0 \\
0 \\
\end{array}$ & $\begin{array}{l}0.0 \\
0 \\
\end{array}$ & 100 \\
\hline $\begin{array}{l}\mathrm{C} \\
\mathrm{d}\end{array}$ & $\begin{array}{l}0.0 \\
1\end{array}$ & $\begin{array}{l}0.0 \\
0\end{array}$ & $\begin{array}{l}0.0 \\
5\end{array}$ & 0.13 & $\begin{array}{l}0.1 \\
1\end{array}$ & $\begin{array}{l}0.1 \\
1\end{array}$ & $\begin{array}{l}0 . \\
00 \\
12 \\
\end{array}$ & $\begin{array}{l}0.00 \\
12\end{array}$ & $\begin{array}{l}0.0 \\
012\end{array}$ & $\begin{array}{l}0 . \\
00 \\
12 \\
\end{array}$ & $\begin{array}{l}0.0 \\
01\end{array}$ & $\begin{array}{l}0.0 \\
01\end{array}$ & $\begin{array}{l}0.00 \\
20\end{array}$ & $\begin{array}{l}0.0 \\
030\end{array}$ & $\begin{array}{l}0.0 \\
02 \\
5 \\
\end{array}$ & 0.06 \\
\hline $\mathrm{V}$ & $\begin{array}{l}0.0 \\
0\end{array}$ & $\begin{array}{l}0.0 \\
0\end{array}$ & $\begin{array}{l}0.0 \\
0\end{array}$ & 0.00 & $\begin{array}{l}0.0 \\
0\end{array}$ & $\begin{array}{l}0.0 \\
0\end{array}$ & $\begin{array}{l}0 . \\
00\end{array}$ & 0.00 & $\begin{array}{l}0.0 \\
0\end{array}$ & $\begin{array}{l}0 . \\
00\end{array}$ & $\begin{array}{l}0.0 \\
0\end{array}$ & $\begin{array}{l}0.0 \\
0\end{array}$ & 0.00 & $\begin{array}{l}0.0 \\
0\end{array}$ & $\begin{array}{l}0.0 \\
05\end{array}$ & 100 \\
\hline
\end{tabular}

$\mathrm{U}_{1} \quad$ Umuaja dry season

$\mathrm{U}_{2} \quad$ Umuaja rainy season

$\mathrm{O} \quad$ Obiaruku dry season

$\mathrm{O}_{2} \quad$ Obiaruku rainy season

$\mathrm{Abk}_{1} \quad$ Abraka dry season

$\mathrm{Abk}_{2}$ Abraka rainy season

$A_{1}$. Agholokpe dry season

$\mathrm{A}_{2} \quad$ Agholokpe rainy season.

$\mathrm{S}_{1} \quad$ Sapele dry season

$\mathrm{S}_{2} \quad$ Sapele rainy season

The mean concentration of $\mathrm{Zn}$ in the sediment samples analysed in this study generally exceeded those of $\mathrm{Pb}, \mathrm{Ni}, \mathrm{Mn}, \mathrm{Cu}, \mathrm{Cd}$ and $\mathrm{V}$. Highest mean concentration of $\mathrm{Zn}$ was found in sediment collected from Sapele axes of the Ethiope river $\left(2.24 \mathrm{mgkg}^{-1}\right)$. This may be attributed to the industrial nature of Sapele. However, this mean concentration of zinc obtained was lower than the mean values recorded for sediments from gutter road side in Warri $^{[12]}$, for Ase River sediments ${ }^{[13]}$, for Kubanni dam sediments containing high levels of heavy metals $^{[14]}$, in Kaduna Street soils ${ }^{[15]}$, but higher than the levels observed in soils around some oil-spill and gas flaring zones in Delta State, Nigeria ${ }^{[16]}$. Zinc is widely used in industries to make dye, paint, rubber, wood preservatives and ointments. Plants and animals require zinc for normal growth. At high concentration, zinc is very toxic, its toxicity being caused by interactions in plant uptake of other essential elements like phosphorus and iron $^{[17]}$.

$\mathrm{Pb}$ concentration was also higher in Sapele area $\left(0.72 \mathrm{mgkg}^{-1}\right)$ compared to other portions of the study area. This could be as a result of the greater amount of hydrocarbon fuels that come out of vehicle exhaust in 
Sapele area. This relatively low level of Pb concentration also exceeds the level reported ${ }^{[6]}$. Toxic concentrations of $\mathrm{Pb}$ can accumulate in bone marrow where red blood corpuscles formation occurs ${ }^{[18]}$.

The average concentration of $\mathrm{Fe}$ in the river sediments was found to be highest in sediment sample collected from Abraka area $\left(4.93 \mathrm{mg} / \mathrm{kg}^{-1}\right)$ followed by the Umuaja end of the catchments $(2.30 \mathrm{mg} / \mathrm{kg})$. The concentration of $\mathrm{Fe}$ to an extent is usually determined by the nature of soils along the river course ${ }^{[19]}$ which is eventually leached into the river system and its sediments. Cu levels recorded were generally low (0.34-0.59 $\mathrm{mg} / \mathrm{kg}$ ). The extremely low levels of $\mathrm{Ni}$ and $\mathrm{Mn}$ which ranged between $0.005-0.74 \mathrm{mg} / \mathrm{kg}$ and $0.21-0.46$ $\mathrm{mg} / \mathrm{kg}$ respectively are relatively lower than the respective values in the world standard for $\mathrm{Ni}$ and $\mathrm{Mn}$ respectively. The average levels of $\mathrm{Cd}$ and $\mathrm{V}$ were very negligible. $\mathrm{Cr}$ was not detected in any of the samples.

Table 2: Elements correlation coefficient of results

\begin{tabular}{|l|c|c|c|c|l|l|l|l|l|}
\hline & $\mathrm{Fe}$ & $\mathrm{Mn}$ & $\mathrm{Zn}$ & $\mathrm{Cu}$ & $\mathrm{Cr}$ & $\mathrm{Cd}$ & $\mathrm{Ni}$ & $\mathrm{V}$ & $\mathrm{Pb}$ \\
\hline $\mathrm{Fe}$ & 1 & 0.060 & 0.014 & 0.40 & -0.17 & -0.06 & -0.19 & -0.01 & 0.01 \\
\hline $\mathrm{Mn}$ & & 1 & 0.44 & 0.48 & 0.20 & 0.29 & 0.31 & 0.32 & 0.30 \\
\hline $\mathrm{Zn}$ & & ++ & 1 & 0.42 & 0.66 & 0.05 & 0.44 & 0.50 & -0.02 \\
\hline $\mathrm{Cu}$ & ++ & ++ & ++ & $\mathrm{I}$ & 0.19 & 0.04 & 0.26 & 0.50 & 0.45 \\
\hline $\mathrm{Cr}$ & & & +++ & & 1 & 0.23 & 0.63 & 0.67 & 0.02 \\
\hline $\mathrm{Cd}$. & & & & & $\cdot$ & 1 & 0.17 & 0.28 & 0.16 \\
\hline $\mathrm{Ni}$ & & & ++ & & +++ & & 1 & 0.58 & 0.07 \\
\hline $\mathrm{V}$ & & & +++ & +++ & +++ & & +++ & 1 & \\
\hline $\mathrm{Pb}$ & & & & ++ & & & & ++ & 1 \\
\hline
\end{tabular}

+ Correlation is significant at the 0.05 levels (2-tailed)

++ Correlation is significant at the 0.01 levels (2-tailed)

The nine heavy metals were grouped according to correlation levels (Table 2). In group 1, the elements $\mathrm{Cr}$. Zn, Ni and V strongly correlated with each other. $\mathrm{Fe}, \mathrm{Zn}, \mathrm{Mn}, \mathrm{Cu}$ and $\mathrm{Ni}$ in group 2, displayed positive correlations of different levels with one another. In group 3, $\mathrm{Cd}$ did not correlate with $\mathrm{Cu}$. Elements of group I have similar ionic radii and exhibit similar chemical behaviour during sediment formation ${ }^{[20]}$. Cd appeared slightly evenly distributed but showed no correlation with other metals.

\section{Conclusion}

Generally the results obtained in this study showed low levels of heavy metal accumulation in the sediments of River Ethiope. This does not pose any threat to the aquatic life. Based on the overall pollution status of River Ethiope observed from the study, recreational and occupational activities in the river can therefore be encouraged.

\section{References}

[1] A.G. Korcharyan, E.V. Venitsianove, N.S. Safronova, and E.P. Serenkaya, Seasonal variation in the forms of heavy metals occurrence in the Water . 2003, 4: 404-412..

[2] C.K. Jain, Metal fractionation study on bed sediments of River Yamuna. India. Water Res.. 2005, 38: 569-578.

[3] B. Gumgum, and G. Ozturk, Chemical speciation of heavy metals in the Tigris River sediment. Chem. Spec. Bioavail . 2001, 13: 25-29.

[4] S.E. Kakulu, O. Osibanjo, and S.O. Ajayi, Trace metals contents of fish and shell fishes of the Niger Delta Area of Nigeria. Environ. Inter. 1987, 13: 247-251.

[5] B.C.O. Okoye, Heavy metals and organisms in the Lagos lagoon. Inter. Studies 1991, 37: 285-295

[6] T.P. Fugeyin, Heavy metals concentrations in water, sediment and fish species of.Ikpoba reservoir, Benin City. Ph.D Thesis University of Benin, Benin City, Nigeria 1994, 167.

[7] O. Idodo-Umeh, Pollution assessment of 0.omoro water bodies using physical, chemical and biological indices. Ph.D Thesis University of Benin, Beam City, Nigeria. 2002, P485.

[8] M. Horsfall, and A.I. Spiff, Speciation and b availability of heavy metals in sediments of Diobis River. Port Harcourt, Nigeria. Euro. J. Sci. Res. 2005, 6(3): 20-36.

[9] D.R. Turner, The chemistry of metal pollutants in water. In: Harrison, R.M. (ed). Pollution: causes, effects and control. U.S. Geological Survey Circular 1013.1981, 613.

[10] D.S. Orhor, Soil chemistry. Russian Translation Series 92. Balkema Publishers, USA. 1992, 5-6.

[11] R.B. Ikomi, The biology of the African Leaf Polycentropsis Abbreviata Boulenger, 1901, in the River Ethiope, Nigeria Acta I Chihyologica et piscaloria 1996, 26: 1-3. 
[12] S.H.O. Egboh, G.E. Nwajei, and E.O. Adaikpoh, Selected heavy metals concentrations in sediments from major roads and gutters in Warri, Delta State, Nigeria. Nig. J. Sci. $\quad$ Environ. $\quad$ 2000,

C.M.A. Iwegbue, M.O. Eghwrudje, G.E. Nwajei, and S.H.O Egboh, Chemical speciation of heavy metals in the Ase River sediments, Niger Delta, Nigeria. Chem. Spec. Bioavail. 2007, 19(13): 119-129.

[14] B.W. Tukura, J.A. Kagbu, and C.E. Gimba, Effects of p11 and total organic carbon (TOC) on the distribution of trace metals in Kubanni Dam sediments, Zaria, Nigeria. Sci. World J. 2007, 2(3): 1-6.

[15] V.O. Ajibola, and I. Ozigis, Partitioning of some heavy metals in Kaduna street Soils. J. Chem. Soc. Nig. 2005, 30(1): 62-66.

[16] E. Osabohien, and O.B. Otuya, Heavy metals in soils, tubers and leaves of cassava plants grown around some oil-spill and gas flaring zones in Delta State, Nigeria. Euro. J. Sci. Res. 2006, 13(1): 53-57.

[17] P.R. Harrison, W.R. Matson, and Ehester, Effects of Cd, Pb and Hg in living organisms. J. Atoms Environ. $1974,5: 613$.

[18] B.J. Alloway, The origin of heavy metals in soils. In: Alloway B.J. (ed) Heavy metals in soils. Blackie, Glasgow and London 1990, 29-30.

[19] A.O. Ekakitie, The potentials of Warn and Ethiope Rivers towards the establishment of fish ponds in Abraka. J. Agric. 1991, 1: 7074.

[20] A. Kabata-Pendias, and H. Pendias, Trace elements in soils and plants. CRS Press. Boca Raton, Florida. 1992. 